\title{
SCIENTIFIC REP RTS OPEN Publisher Correction: Examining a Thermodynamic Order Parameter of Protein Folding
}

\section{Song-Ho Chong \& Sihyun Ham}

Correction to: Scientific Reports https://doi.org/10.1038/s41598-018-25406-8, published online 08 May 2018

The original version of this Article was published with an incorrect version of the Supplementary Information file due to a technical error. This has now been corrected in the HTML; the PDF version of the paper was correct from the time of publication.

cc) (i) Open Access This article is licensed under a Creative Commons Attribution 4.0 International License, which permits use, sharing, adaptation, distribution and reproduction in any medium or format, as long as you give appropriate credit to the original author(s) and the source, provide a link to the Creative Commons license, and indicate if changes were made. The images or other third party material in this article are included in the article's Creative Commons license, unless indicated otherwise in a credit line to the material. If material is not included in the article's Creative Commons license and your intended use is not permitted by statutory regulation or exceeds the permitted use, you will need to obtain permission directly from the copyright holder. To view a copy of this license, visit http://creativecommons.org/licenses/by/4.0/.

(c) The Author(s) 2018 